\title{
Phytochemical Screening and Biological Activities of Combretum adenogonium Leaves Extracts
}

\author{
Martial S. Nounagon \\ Durand Dah-Nouvlessounon \\ Christine N'tcha \\ Sani M. Akorede \\ Haziz Sina
}

Laboratory of biology and molecular typing in microbiology, Faculty of Sciences and Techniques/University of Abomey-Calavi, Cotonou, Bénin

\section{Pacôme A. Noumavo}

Laboratory of biology and molecular typing in microbiology, Faculty of Sciences and Techniques/University of Abomey-Calavi, Cotonou, Bénin.

Laboratoire deMicrobiologie et Technologie Alimentaire, Université d'Abomey Calavi, Cotonou, Benin.

\section{Farid Baba-Moussa}

Laboratoire deMicrobiologie et Technologie Alimentaire,

Université d'Abomey Calavi, Cotonou, Benin.

\section{Farid Bade}

Laboratoire de Microbiologie, Section Eau Hygyene et Aliment, Ministère de la Santé Cotonou Benin

\section{Adolphe Adjadohoun}

Centre de Recherche Agricole Sud. Institut National de Recherche Agricole du Benin. Attogon, Cotonou Benin

\section{Lamine Baba-Moussa}

Laboratory of biology and molecular typing in microbiology, Faculty of Sciences and Techniques/University of Abomey-Calavi, Cotonou, Bénin

Doi: 10.19044/esj.2017.v13n30p358 URL:http://dx.doi.org/10.19044/esj.2017.v13n30p358

\begin{abstract}
Combretum adenogonium is beniniens pharmacopoeia medicinal plant used for the treatment of various diseases. This work aims to study the phytochemical and assess some biological activities of $C$. adenogonium leaves extracts. The phytochemical analysis (qualitative et quantitative) was conducted by standard analytical chemistry method. Antioxydant activity was evaluated by the DPPH method. Antibacterial activity was evaluated in vitro with 10 references strains, 10 Staphylococcus strains isolated from
\end{abstract}


meat products and 10 clinical Staphylococcus aureus strains isolated from Buruli ulcer lesions and pus. The Minimum Inhibitory Concentration (MIC) and Bactericidal (CMB) were determined by macrodilution method. The extracts cytotoxic effect was evaluated with Artemia salina larvae. The phytochemical screening revealed the presence of flavonoids, tannins, anthocyanins, saponin and triterpenoids. The methanolique extract present the higest content $(450.66 \pm 0.004 \mu \mathrm{g}$ EAG/mg) of total polyphenolic compound. The results showed the good antioxidant activity. The inhibitory diameter zone vary $(p<0.001)$ according to the strains. The largest medium inhibitory diameter $(21.85 \pm 0.17 \mathrm{~mm})$ was obtained with the ethanolic extract, while the lowest $(6.00 \pm 0.00 \mathrm{~mm})$ were recorded with water-ethanol extract. The variation between CMI and CMB is not significant $(p>0.05)$. The higher LD $_{50}(27.66 \mathrm{mg} / \mathrm{ml})$ was recorded with methanol extract. The results of this study confirm some use of $C$. Adenogonium extracts. But; these extracts must be use with moderation.

Keywords: C. adenogonium, phytochemistry, biological activities, cytotoxicity, Benin

\section{Introduction}

The use of natural products, known as sources of antioxidants, is becoming more and more rare, and many diseases related to the phenomenon of oxidative stress have emerged. The latter is involved in various pathologies such as cardiovascular disease, cancers, diabetes, dementia (Alzheimer, Parkinson) and the aging process (Aruoma, 2003). Thus, human health became precarious. In this situation, the cell can't control the excessive presence of toxic oxygen radicals in our body, made by human food practice change, pollution, more and more growing in our world (Defraigne and pass, 2007).

Scientific advances were able to show that natural products like plants can be huge sources of antioxidants and allow to counteract the pathological disorders associated with oxidative stress in the body. Cells use many antioxidant strategies and consume a lot of energy to control their level of reactive species of oxygen (Bouabdallah, 2014). Excess of reactive species of oxygen-related diseases are very common and there is a particular interest, through the search for new sources of antioxidant molecules. This interest is all the more remarkable in regard to the infectious diseases. They are a major public health problem in the world and particularly in Africa. They are responsible for 45 percent of deaths in countries with low income and almost a premature mortality in the world (Konan et al., 2014). Among infectious diseases, those caused by bacterial infections account for $70 \%$ of cases of mortality (Walsh, 2003). However, because of uncontrolled use, 
inadequate and misuse of antibiotics in human and veterinary health, now there is the emergence of Multiresistant bacteria (Savard, 2003). The emergence and dissemination of these Multiresistant bacteria in human populations became public health issues of serious concern (Lozniewski and Rabaud 2010). The progression of the multi-resistance and the absence of real prospects for the discovery of new antibiotics in the years to come, led us to study the effectiveness of medicinal plants in order to isolate the active principles.

Traditional medicine remains the main use of a large majority of the population to solve their health problems (Kone, 2009). The who estimated in 2007 that about $80 \%$ of the population of developing countries have recourse to traditional medicine for their primary health need. Today, everywhere in Africa, the problem of costs and / or access to conventional medicines in rural areas, people turn more and more to the traditional, inexpensive and sometimes more effective medicine according to the popular belief. In Benin, many plants are used by the Beninese people to combat the diseases. Adjanohoun and al. (1989) have identified nearly 501 species used in traditional medicines in Benin. Also, Sinsin and al. (2000) identified 814 species belonging to 130 botanical families with medicinal virtues. $C$. adenogonium is one of the 140 species of the genus Combretum, native to tropical Africa and belonging to the family of the Combretacees. It is known for its digestive, insecticidal, antifungal, antiproliferative and cytotoxic properties in West Africa (Maregesi et al., 2008).

Given the complications and difficulties in the treatment of diseases and endogenous knowledge acquired from the traditional healers on $C$. adenogonium in the treatment of various ailments, several scientists have worked on this plant to determine her principle active and its mode of action in order to confirm or disprove these endogenous knowledge on the one hand and relieve patients on health and financial other hand. Moreover, few data are available on Antimicrobial, antioxidant, cytotoxic activity and the mechanism of cellular action of this plant. This work aims to study the phytochemistry and evaluate some biological activity of $C$. adenogonium leaves extracts.

\section{Material and methods \\ Biological material}

It consists on the one hand of the extracts obtained with Combretum adenogonium leaves. Moreover, The tested microrganisms include both bacteria (Gram positive and Gram negative) and yeast. These microorganisms are composed of:

Ten references strains (Escherichia coli ATCC 25922, Staphylococcus aureus ATCC 29213, Staphylococcus epidermidisT22695, 
Pseudomonas aeruginosa ATCC 27853, Proteus mirabilus A24974, Micrococcus luteus ATCC10240, Proteus vulgaris A25015, Streptococcus oralis, Enterococcus foecalis ATCC 29212 and Candida albicans MHMR).

Ten Staphylococcus species (S. hominis, S. chromogenes, S. sciuri, S. simulans S. xylosus, S. cohnii, S. aureus, S. auricularis, S. capitis and $S$. coprae) isolated from meat products in Ivory Coast by Attien et al. (2013) and stored in the Laboratory of Biology and Molecular Typing in Microbiology (University of Abomey-Calavi, Benin).

\section{Collection of plants material}

The $C$. adenogonium leaves were collected in Tanguiéta and Kalale in March 2016. After harvest, the leaves were washed with water and dried in the laboratory $\left(25 \pm 2{ }^{\circ} \mathrm{C}\right.$ ) for 15 days. They were then powdered using a grinder Retsch type SM 2000/1430/pUm/Smfand. The powders were used for different extractions.

\section{Phytochemical screening}

The qualitative phytochemical screening a chemical analysis is performed based on colouring or precipitation reactions. It is made directly on the powder of the $C$. adenogonium leaves according to Houghton and Raman (1998).

\section{Preparation of aqueous, ethanol ethyl acetate, hexanic and methanolique extracts}

The extract were obtained according to the method describe by DahNouvlessounon et al. (2015) and N'Guessan et al. (2007). Briefly, the leaf powder $(50 \mathrm{~g})$, was macerated into $500 \mathrm{ml}$ of each solvent (water, ethanol, ethyl acetate and dichloromethane) under agitator for $72 \mathrm{~h}$ at room temperature. The each homogenate was then filtered two times on absorbent cotton and once on Whatman $\mathrm{N}^{\circ} 1$ paper $(125 \mathrm{~mm} \varnothing$, Cat No 1001 125). For the aqueous extract the filtrate was dried in the oven at $40^{\circ} \mathrm{C}$. While for the organic (ethanol, ethyl acetate and dichloromethan) extract the filtrate were concentrated in vacuum using a rotary evaporator (Heidolph Instruments GmbH \& Co. KG No: 591-28000-00-1) to obtain the extract. All extracts were stored in labeled sterile bottles and kept at $-20^{\circ} \mathrm{C}$ until further use.

\section{Determination of extracts yield}

The performance of the crude extract is defined as the ratio between the mass of the dry extract obtained and the mass processed plant material (Harborne, 1998). This yield is calculated using the following formula:

$$
\mathrm{R}(\%)=\frac{\text { Extract weight }}{\text { Powder weight }} \times 100
$$




\section{Determination of the phenolic compounds}

Total polyphenols were determined by using adapted Folin-Ciocalteu method as described by Singleton et al. (1999). Briefly, the methanolic solution of each extract $(10 \mathrm{mg} / \mathrm{ml})$ was diluted to $1 / 100$ with distilled water. $125 \mu 1$ of this solution was then mixed with $625 \mu 1$ of Folin-Ciocalteu reagent (10\%). After $5 \mathrm{~min}, 500 \mu \mathrm{l}$ of aqueous sodium carbonate $\left(\mathrm{Na}_{2} \mathrm{CO}_{3} ; 75 \mathrm{~g} / \mathrm{l}\right)$ were added. After $2 \mathrm{~h}$ of incubation in dark at the room temperature, the absorbances were measured in triplicate at $760 \mathrm{~nm}$ against a blank $(0.5 \mathrm{ml}$ Folin-Ciocalteu and $1 \mathrm{ml}$ of $\mathrm{Na}_{2} \mathrm{CO}_{3}$ ) with spectrophotometer (BIOMATES $3 \mathrm{~S})$. The total phenolics content was determined using the plotted standard calibration curve with gallic acid $(0-10 \mathrm{mg} / \mathrm{ml})$.

\section{Total flavonoïds content}

The total flavonoids were determined according to the adapted method of Kim et al. (2003) Aliquots were prepared by mixing of $500 \mu 1$ of extract solution $(10 \mathrm{mg} / \mathrm{ml}), 500 \mu \mathrm{l}$ of méthanolic solution of $\mathrm{AlCl}_{3}(2 \%)$ and $3 \mathrm{ml}$ of methanol. After $10 \mathrm{~min}$ of incubation, the absorbances were measured at $415 \mathrm{~nm}$ against a blank $\left(500 \mu \mathrm{ld} \mathrm{d}^{\prime} \mathrm{AlCl}_{3}\right.$ and $3.5 \mathrm{ml}$ of méthanol) by using spectrophometer. A standard calibration curve $\left(R^{2}=1\right)$ was plotted using rutine $(0-150 \mu \mathrm{g} / \mathrm{ml})$. The data obtained were the means of three determinations. The amounts of flavonoids in the bark and leave extracts were expressed as $\mu \mathrm{g}$ of rutine equivalents (RE)/mg of extract.

\section{DPPH radical-scavenging essay}

This test was evaluated using the procedure described by LamianMédard et al. (2008) it is based on the reduction of the stable free radical DPPH in the presence of a radical donor $\mathrm{H}^{+}$to the $517 \mathrm{~nm}$ wavelength. Briefly, a mass of $1 \mathrm{mg}$ of the extract was dissolved in $1 \mathrm{ml}$ of methanol $(\mathrm{C}=$ $1 \mathrm{mg} / \mathrm{ml}$ ). The resulting solution is then diluted to $1 / 100^{\text {th }}$. To prepare the solution of DPPH, $4 \mathrm{mg}$ of powder of DPPH was dissolved in $10 \mathrm{ml}$ of methanol to have a mass concentration of $0.4 \mathrm{mg} / \mathrm{ml}$. Then $1.5 \mathrm{ml}$ of the extract (diluted) were mixed with $3 \mathrm{ml}$ of DPPH methanolique solution. The mixture was incubated for 15 minutes in darkness at room temperature; the absorbance is read at $517 \mathrm{~nm}$ against a constituted white DPPH and methanol. The extracts anti-radical activity was determined using a calibration curve established with vitamin C $(0-10 \mathrm{mg} / \mathrm{ml})$. Each test was conducted in triplicatas.

\section{Anti microbial activity assessment methods Sensitivity test}

It was done according to the disc method inspired from the one described by Bauer et al. (1966). Brieflt, $1 \mathrm{ml}$ of pre-culture of 18-24 h $\left(10^{6}\right.$ 
UFC/ml) enabled planting a box of Petri dishes containing agar Mueller Hinton by flood. After seeding, the sterile Whatman paper discs $(5 \mathrm{~mm}$ de diameter) were deposited with sterile pince. These discs have been carefully impregnated with $30 \mu 1$ of plant extract $(20 \mathrm{mg} / \mathrm{ml}$. The dishes were kept for $15-30 \mathrm{~min}$ at room temperature before incubation at $37^{\circ} \mathrm{C}$. The inhibition zones diameters were measured after 24 to 48 hours (Adesokan et al., 2007) using a ruler graduated. For each extract, the experiment was performed in duplicate.

\section{Determination of the Minimum Inhibitory Concentration (MIC)}

The MIC has been determined by macrodilution method (Delarras, 1998) with Visual assessment of the growth of microorganisms. Briefly, nine concentrations $(10000,5000,2500,1250,625,312.5,156.25,78.12$ and $39.06 \mu \mathrm{g} / \mathrm{ml}$ ) was performed in screw tube. To $1 \mathrm{ml}$ of the above concentrations was added $1 \mathrm{ml}$ of the bacteria inoculum $\left(10^{6} \mathrm{UFC} / \mathrm{ml}\right)$. After $24 \mathrm{~h}$ of incubation turbidity tubes was examined relative to the control tube containing distilled water and the inoculum $\left(10^{6} \mathrm{UFC} / \mathrm{ml}\right)$.

\section{Determination of the Minimum Bactericidal Concentration (MBC)}

The MBC was determined by solid medium culture of all of the tubes from the MIC to high concentrations. These dishes were incubated at $37^{\circ} \mathrm{C}$ for $24 \mathrm{~h}$. The highest dilution that yielded no bacterial growth on solid medium was taken as MBC (Farshori et al., 2013)

\section{Cytotoxicity activity of $C$. adenogonium extracts}

This test was evaluated according to the adaptation of the method described by Kawsar et al., (2008). The tests were conducted on larvae obtained by outbreak of $10 \mathrm{mg}$ of Artemia salina (ARTEMIO JBL GmbH D to 67141 Neuhofem) under continuous stirring in 11 of seawater for 72 hours. A $1 \mathrm{ml}$ of each dilution in geometric series of reason $1 / 2$ extract prepared from a stock solution of $20 \mathrm{mg} / \mathrm{ml}$, in sea water, $1 \mathrm{ml}$ of seawater containing 16 larvae has been added. The number of surviving larvae was counted after $24 \mathrm{~h}$ of incubation. The $\mathrm{DL}_{50}$ has been determined from the regression line obtained from the representative curve in the number of surviving larvae based on the concentration of extracts. Each test was performed in duplicate.

\section{Data treatment and analysis}

The spreadsheet Microsoft Excel version 2010 has been used for the capture and encoding the data. Minitab (version 17) software was used for the variance analysis (ANOVA). Finally a structuring of the medium was made which allowed us to compare and identify the excerpt (s) most active 
on the various parameters through Student Newman and Keuls (SNK) test on the threshold of $5 \%$ of significance.

\section{Results}

\section{The extraction performance}

Table 1 shows the yield of the extracts. Methanol and ethanol gave the highest yield respectively $12.8 \%$ and $12.49 \%$. While the lowest yield $(0.5 \%)$ was recorded with the hexanique extract. The extraction of each solvent capacity analysis shows that the largest number of compound may have biological activities is extracted by methanol.

Table 1: Extracts yield from C. adenogonium leave according to the solvent

\begin{tabular}{ccccccc}
\hline $\begin{array}{c}\text { Types of } \\
\text { extracts }\end{array}$ & Aqueous & water-ethanol & Ethanol & Hexanique & Methanol & $\begin{array}{c}\text { Ethyl } \\
\text { acetate }\end{array}$ \\
\hline $\begin{array}{c}\text { Powder } \\
\text { mass (g) }\end{array}$ & 200 & 100 & 200 & 40 & 25 & 40 \\
$\begin{array}{c}\text { Extracts } \\
\text { mass (g) }\end{array}$ & 12.67 & 6.6 & 24.98 & 0.2 & 3.2 & 1.4 \\
Yield (\%) & 6.35 & 6.6 & 12.49 & 0.5 & 12.8 & 3.5 \\
\hline
\end{tabular}

\section{Phytochemical screening}

The phytochemical screening shows that $C$. adenogonium leaves powder is rich in natural chemicals such as flavonoids, tannins, anthocyanins, leucoanthocyanes and the triterpenoids. While some secondary metabolite such as alkaloids, steroids, cyanogeniques derivatives and $\mathrm{O}$ glycosides were absent (Table 2).

Table 2: Phytochemicals contituents of $C$. adenogonium leaves powder .

\begin{tabular}{cc}
\hline Chemical compound & leaf \\
\hline Alkaloids & - \\
Tannins & +++ \\
Saponins (MI) & $+++(167)$ \\
Anthocyanins & +++ \\
Leuco-anthocyanins & +++ \\
Flavonoids & +++ \\
Steroids & - \\
Triterpenes & +++ \\
Coumarin & +++ \\
Reducing compound & +++ \\
Glycosids & + \\
O-Hétérosids & - \\
Cyanogenic derivate & - \\
\hline
\end{tabular}

+: Low color intensity, +++: high color intensity - : absence of coloration; MI : index moss

\section{Antioxidant capacities (DPPH radical scavenging)}

Equivalent Ascorbic acid content in each extract are presented in figure 2. Ethyl acetate extract shows high value $(6.5 \pm 0.11 \mathrm{mM})$ while the lowest $(18.2 \pm 0.01 \mathrm{mM})$ was recorded with aqueous extract. 


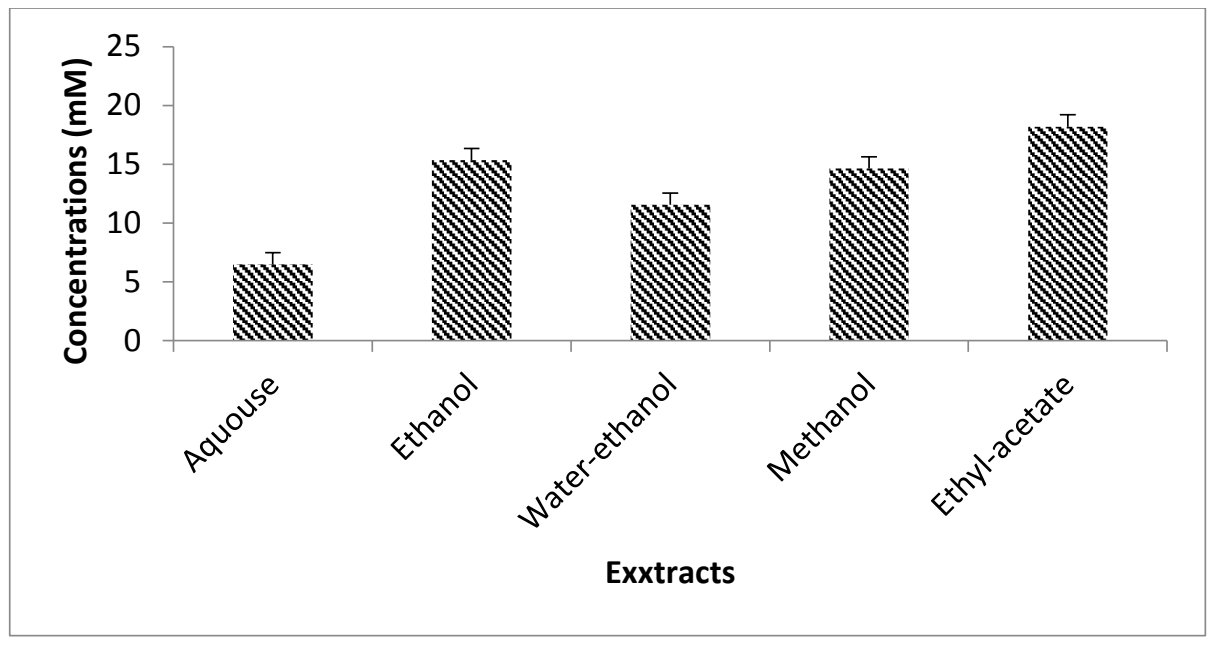

Figure 2: Equivalent Ascorbic acid content of C. adenogonium extracts

\section{Total polyphenols and flavonïdes contents}

Concentrations of total polyphenols and flavonoïds are determined from the calibration right $\left(\mathrm{y}=0.0787 \mathrm{x}-0.0379 ; \mathrm{R}^{2}=0.996\right)$ drawn using as standard the Gallic acid and rutin respectively. The results are presented in table 2. The methanolique extract has the highest $(450.66 \pm 0.004 \mu \mathrm{g}$ $\mathrm{EAG} / \mathrm{mg}$ of extract) total polyphenols contents while ethyl acetate extract have the lowest $(97.93 \pm 0.005 \mu \mathrm{g}$ EAG/mg of extract).

Table 2: Total polyphenols and flavonoïds content of $C$. adenogonium extracts

\begin{tabular}{|c|c|c|}
\hline Extracts & $\begin{array}{c}\text { Total Polyphenols } \\
(\mu \mathrm{g} \text { EAG } / \mathrm{mg})\end{array}$ & $\begin{array}{c}\text { Total Flavonoïds } \\
(\mu \mathrm{g} \text { ER/mg })\end{array}$ \\
\hline Aqueous & $204.25 \pm 0.001$ & $492.25 \pm 2.52$ \\
\hline Ethanol & $164.00 \pm 0.005$ & $615.31 \pm 4.91$ \\
\hline Water-ethanol & $168.88 \pm 0.004$ & $485.42 \pm 0.93$ \\
\hline Methanol & $450.66 \pm 0.004$ & $537.14 \pm 2.24$ \\
\hline Ethyl acetate & $97.93 \pm 0.005$ & $662.20 \pm 2.52$ \\
\hline
\end{tabular}

EAG: Equivalent Gallic acid; ER: Equivalent rutin

\section{Antibacterial activity of $C$. adenogonium extracts on reference strains}

Table 3 shows antibacterial profile of $C$. adenogonium leaves extracts with the references strains. The analysis of these results shows that only the hexanique $(20 \mathrm{mg} / \mathrm{ml})$ did not inhibit the growth of these strains. For this purpose, only hexane extract has not taken into consideration for the antibacterial tests. all of the reference strains are sensitive to different extracts except the hexanique extract. The aqueous extract of the leaves has no effect on the strains tested at the dose of $20 \mathrm{mg} / \mathrm{ml}$ but at a dose of 50 $\mathrm{mg} / \mathrm{ml}$, strains such as $P$. vulgaris, $S$. oralis, E. foecalis, E. coli are resistant to its activity. At the dose of $20 \mathrm{mg} / \mathrm{ml}$, only hexanique and aqueous extracts. 
Table 3: Antibacterial activity of $C$. adenogonium extracts with reference strains

\begin{tabular}{ccccccc}
\hline Reference strains & EA & EE & EHE & EM & EH & EAT \\
\hline S. aureus ATCC 29213 & + & + & + & + & - & + \\
P. aeruginosa ATCC 27853 & + & + & + & + & - & + \\
P. mirabilis A24974 & + & + & + & + & - & + \\
M. luteus ATCC10240 & + & + & + & + & - & + \\
S. epidermidis T22695 & + & + & + & + & - & + \\
P. vulgaris A25015 & - & + & + & + & - & + \\
S. oralis & - & + & + & + & - & + \\
E. foecalis ATCC 29212 & - & + & + & + & - & + \\
E. coli ATCC 25922 & - & + & + & + & - & + \\
C. albicans MHMR & + & + & + & + & - & + \\
\hline
\end{tabular}

+: inhibiton; -: no inhibition; EA: Aqueous extract; EE: Ethanol Extract; EHE: Water-

Ethanol extract; EM: Methanol extract; EH: Hexane Extract; EAT: Ethyl acetate extract.

\section{The extracts inhibitory diameter zone with the reference strains}

The inhibitory diameter zone of the sensitive strains vary $(p<0.001)$ occording to the extracts (Figure 3). For the aqueous extract (Figure 3A) the larger diameter $(12.5 \mathrm{~mm})$ was obtained with $P$. aeruginosa and the lower diameter $(8.5 \mathrm{~mm})$ was obtained with $S$. aureus. The ethanol extract largest diameter $(22 \mathrm{~mm})$ was obtained on $S$. oralis, and the lowest $(9 \mathrm{~mm})$ with $P$. vulgaris (Figure 3B). C. albicans is the reference strains who present the largest inhibitory zone $(13 \mathrm{~mm})$ with the ethyl acetate extract (Figure $3 \mathrm{C}$ ). For the water-ethanol (D), P. vulgaris strain shows the high sensitibility $(13.9 \mathrm{~mm})$ to the extracts, while $E$. coli shows more resistance $(6 \mathrm{~mm})$ against this extracts.
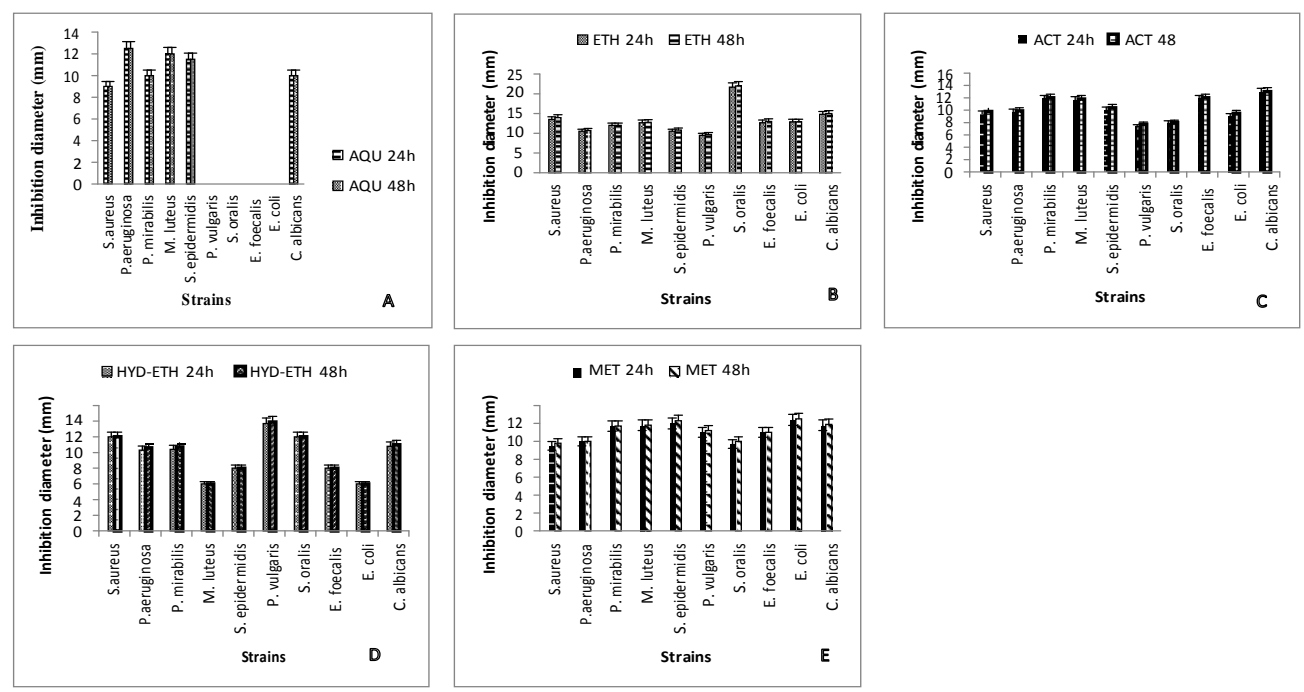

Figure 3: Diameters of inhibition of aqueouse extracts (A) ethanol (B), acetic (C) water ethanol (D) and methanolic (E) C. adenogonium one the strains of reference ( $24 \mathrm{~h}$ et $48 \mathrm{~h}$ ) 


\section{Antibacterial activity of $C$. adenogonium leave extracts against the meat isolated Staphylococcus strains}

Among the differents extract, only the aqueous extract have the lower rate $(40 \%)$ of the tested strains inhibition. Figure 5 show that the inhibitory zone diameter vary according to the strains and the extracts. The Analysis of variance show that these diameter variation were not significant $(p>0.05)$ in the time $(24 \mathrm{~h}$ and $48 \mathrm{~h})$. On the contrary, the difference of the effect between the extracts type was very highly significant $(p<0.001)$. The greatest inhibitory diameters $(17.2 \mathrm{~mm})$ were obtained with the ethanol extract against the strain $S$. coprae. It was following to the methanol extract (17 mm, with $S$. xylosus). The low inhibitory diameter $(7 \mathrm{~mm}$ ) was registred with aqueous extract ( $S$. conhii). The aqueous extract had no effect on the meat isolated Staphylococcus strains such as: S. hominis, S. chromogenes, $S$. xylosus, S. aureus, S. auricularis and S. capitis.

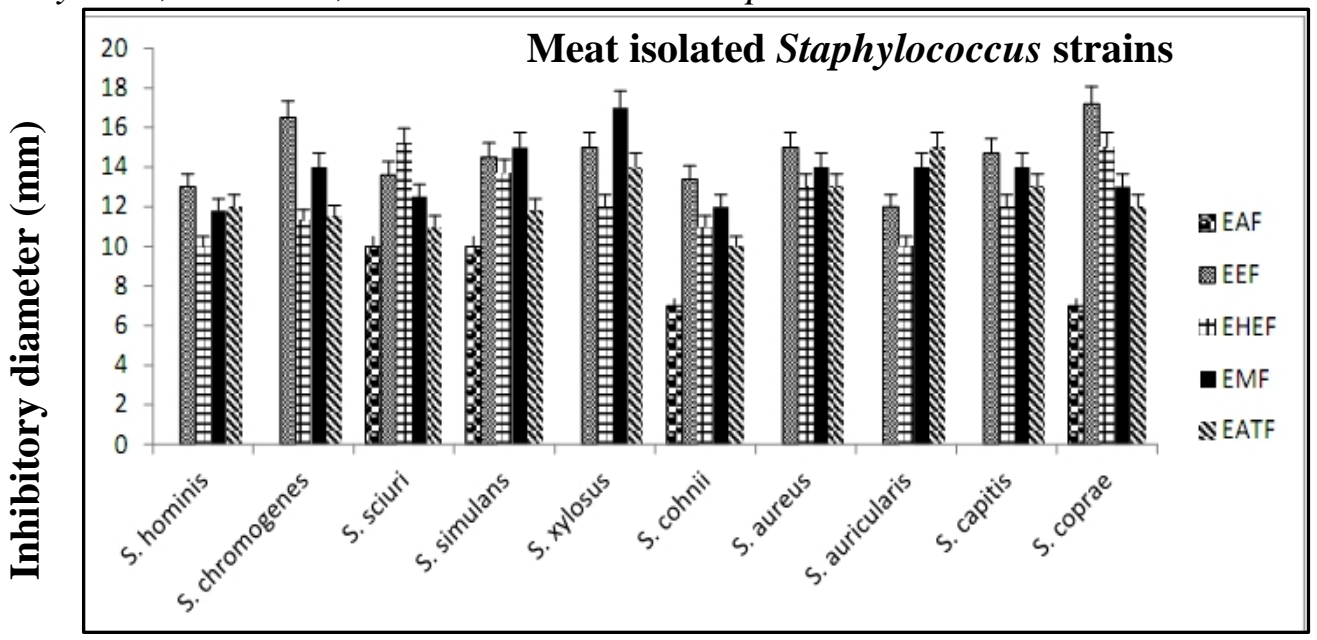

Figure 5: Diameter of inhibition: EAF: Aquoues extract, EEF: Ethanol extract; EHEF:Water-ethanol extract; EMF:Methanol extract; EATF: Ethyl-acetate extract.

\section{Minimum Inhibitory Concentrations of $C$ adenogonium extracts on reference strains}

Minimal Inhibitory Concentrations of the extracts with reference strains are given in table 7 . This table analysis shows that all extract have the MIC lower than the starting concentration $(20 \mathrm{mg} / \mathrm{ml})$. Smallest MIC (1.56 $\mathrm{mg} / \mathrm{ml}$ ) were obtained at least on a reference strains with all the extracts except the water-ethanol extract of which smallest MIC was $2.5 \mathrm{mg} / \mathrm{ml}$. In addition, among the sensitive strains, only $S$. epidermidis and E. coli strains were recorded smallest MIC $(1.56 \mathrm{mg} / \mathrm{ml})$ of two types of extract at the same time. Nevertheless, it is necessary to notice that only the methanol extract had at the same time, smallest MIC with three reference strains ( $S$. epidermidis, E. coli and C. albicans). 
Table 7: Minimum Inhibitory Concentration $(\mathrm{mg} / \mathrm{ml})$ of the extracts on the studied reference strains

\begin{tabular}{cccccc}
\hline \multirow{2}{*}{ Reference strains } & \multicolumn{5}{c}{ MIC $(\mathrm{mg} / \mathrm{ml})$} \\
\cline { 2 - 6 } & EA & EE & EHE & EM & EAT \\
\hline S. aureus ATCC 29213 & 6.25 & 5 & 2.5 & 2.5 & 5 \\
P. aeruginosa ATCC 27853 & 12.5 & 2.5 & 10 & 10 & 2.5 \\
P. mirabilis A24974 & 1,562 & 2.5 & 5 & 5 & 10 \\
M. luteus ATCC10240 & 3.125 & 2.5 & 10 & 10 & 5 \\
S. epidermidis T22695 & 3.125 & 2.5 & 5 & 1.25 & 1.25 \\
P. vulgaris A25015 & - & 10 & 10 & 5 & 1.25 \\
S. oralis & - & 5 & 2.5 & 5 & 2.5 \\
E. foecalis ATCC 29212 & - & 5 & 2.5 & 2.5 & 2.5 \\
E. coli ATCC 25922 & - & 1.25 & 2.5 & 1.25 & 5 \\
C. albicans MHMR & 12.5 & 2.5 & 5 & 1.25 & 10 \\
\hline
\end{tabular}

EA: aqueous extract; EE: Ethanolic extract; EHE: Water-ethanol extract; EM: Methanolic extract; EH: Henanic Extract; EAT: Ethyl acetate extract

\section{Minimum Bactericidal Concentration $(\mathrm{mg} / \mathrm{ml})$ of the extracts on the reference strains}

Minimum Bactericidal Concentrations vary depending on the strains and types of extracts (table 8). The analysis of the table shows that, except the $\mathrm{MBC}(10 \mathrm{mg} / \mathrm{ml})$ obtained with the water-ethanol extract on $P$. vulgaris strain, no extract presented a MBC equal to the MIC although the strain tested. The lowest MBC $(5 \mathrm{mg} / \mathrm{ml})$ was obtained with the ethanol extract on $E$. coli strain. The ethanol extract proved to be most active while the aqueous extracts, methanolic and ethyl acetate extract presented the concentrations superior at those of starting (MBC $>20 \mathrm{mg} / \mathrm{ml}$ ).

Table 8: Minimum Bactericidal Concentrations of extracts with reference strains

\begin{tabular}{cccccc}
\hline \multirow{2}{*}{ SRF } & \multicolumn{5}{c}{ Minimum Bactericidal Concentration $(\mathrm{mg} / \mathrm{ml})$} \\
\cline { 2 - 6 } & EA & EA & EHE & EM & EAT \\
\hline S. aureus ATCC 29213 & $>20$ & 20 & $>20$ & $>20$ & $>20$ \\
P. aeruginosa ATCC 27853 & $>20$ & 20 & $>20$ & $>20$ & $>20$ \\
P. mirabilis A24974 & $>20$ & $>20$ & 10 & $>20$ & $>20$ \\
M. luteus ATCC10240 & $>20$ & $>20$ & $>20$ & $>20$ & $>20$ \\
S. epidermidis T22695 & $>20$ & $>20$ & $>20$ & $>20$ & $>20$ \\
$\boldsymbol{P}$. vulgaris A25015 & - & $>20$ & 10 & $>20$ & $>20$ \\
S. oralis & - & 20 & $>20$ & $>20$ & $>20$ \\
E. foecalis ATCC 29212 & - & 10 & 10 & $>20$ & $>20$ \\
E. coli ATCC 25922 & - & 5 & $>20$ & $>20$ & $>20$ \\
C. albicans MHMR & $>20$ & 20 & $>20$ & $>20$ & $>20$ \\
\hline
\end{tabular}

EA: aqueous extract; EE: Extract Ethanolique; EHE: Water-ethanol extract; EM: Methanolique extract; EH: Henanique extract; EAT: Ethyl acetate extract; 


\section{Cytotoxic activity of $C$. adenogonium extracts}

Table 9 shows the average lethal dose (DL 50 ) according to the extracts as well as correlation coefficients. There is a variation of the DL50 from the regression line obtained from the representative curve in the number of surviving larvae based on the extracts concentration. The higher lethal concentration $(27.66 \mathrm{mg} / \mathrm{ml})$ of $50 \%$ of the larvae (DL 50) was obtained with methanol extract, while the lowest $(2.87 \mathrm{mg} / \mathrm{ml})$ was recorded with ethanol extract.

Table 9: C. adenogonium extracts lethality dose to the Artemia salina larvae

\begin{tabular}{ccc}
\hline Extracts & $\mathrm{DL}_{50}(\mathbf{m g} / \mathbf{m l})$ & $\mathrm{R}^{2}$ \\
\hline Aqueous & 4.39 & 0,54 \\
Ethanol & 2.87 & 0,91 \\
Water-ethanol & 3.04 & 0.91 \\
Methanol & 27.66 & 0.75 \\
Ethyl acetate & 3.29 & 0,78 \\
\hline
\end{tabular}

\section{Discussion}

The research for bioactives molecules resulting from the plants in the treatment of various diseases becomes increasingly necessary for the world of research. In the present study carried out on the $C$. adenogonium leave, the extraction method showed an yield more high (12\%) with methanol. The hexane on the other hand gave the lowest $(0.5 \%)$. The lowest yield obtained with hexane shows that this plant leave do not contain many compound of lipidic nature. The variability observed in relation to the yield extraction with the other solvents would be probably related to the chemical composition of the leave used but also of the physiological state of the plant to harvest. In the same way, the difference in nature of solvents can be also explain this variation because Dah-Nouvlessounon et al. (2015) showed that the capacity of solvent extraction depends on the one hand on the affinity of this solvent with the phytomolécules and on the other hand of the polarity of this solvent.

Many secondary metabolites such as: tanins, flavonoïds, terpen, anthocyanin and saponines were detected in the extracts. This is conforming to the results of Novatus et al. (2012), which revealed the presence of these secondary metabolites in the hydro-ethanol extract of Combretum adenogonium. These metabolites were known for these biological activities such as: antiviral, antibacterial, anti-inflammatory and analgesic activity (Tsuchiya et al. 1996 and Ojewole, 2008). Yahaya et al. (2012) also revealed the presence of flavonoids, , tannins, glycosides, derivatives quinoniques and alkaloids in crude extract of a plant of the same family (Combretum glutinosum). But in this study, only the alkaloids have not been found in the C. adenogonium leaves extracts. It could be explained by factors influencing the plant photosynthesis. The absence of cyanogeniques derivatives in our 
results reinforces the importance of our plant because they are the causes of toxicity due to the production of cyanide ions and manifest by the acceleration and the amplification of respiratory rate, respiratory depression, dizziness, headache, disorder of consciousness, coma deep etc (Bruneton, 1999). The presence of mucilages in the extracts confirms the presence of polysaccharides in the plant (Macdonald, 2010). Polysaccharides are beings alive, a large number of vital functions (breathing, energy metabolism, nutrition). polysaccharides may also be slow release of glucose forms, that can intervene in the regulation and the release of glucose in the diabetic (Macdonald, 2010).

The results show that the largest amount of total phenols was detected in the methanolic extract with an equivalent of Gallic acid up to two times higher compared to the fraction other excerpts. Similar results have been reported by Itoro et al. (2016) with methanolic extract of Combretum platypetalum. Indeed, this high content was positively correlated with its antioxidant capacity, in terms of neutralization of the DPPH radical with equivalent content of 14.63 mmolaire Ascorbic acid per milligram of extract. Similar observations were noted by Zakariat et al. (2011) for the leaves of Melastoma malabathricum where the highest content of the methanolic fraction in polyphenols has been associated with a maximum antioxidant capacity. The results shows that the total polyphenols of ethanol extract content is greater than that of the ethyl acetate extract and is small compared to the total aqueous extract polyphenols content. These results can be explained by the fact that the solvent plays an important role in the solubility of the chemical constituents (Mada, 2013). The production of free radicals in living organisms is a vital phenomenon for the cell regulated through various biochemical or enzymatic detoxification process (Salem, 2009). These free radicals are involved in many serious illnesses and constitute even aggressive form factors to DNA (Boumaza, 2009). Indeed, potential sources of antioxidant compounds have been searched in several types of plant materials such as vegetables, fruits, leaves, barks, roots and crude plant drugs. These antioxidants are vital substances which possess the ability to protect the body from damage caused by free radical induced oxidative stress (Ozoy et al., 2008). The results show that $C$. adenogonium leaves are the natural potential source of antioxidant.

On the antimicrobial activity, four types of extracts (ethanol, waterethanol, methanolic and ethyl acetate) from $C$. adenogonium leaf revealed their efficiencies at $20 \mathrm{mg} / \mathrm{ml}$. On the other hand, with the same concentration, the aqueous extract has proved ineffective. The possible explanation to the difference of activity between the extracts may be the ability of solvent to solubilize and extract some phyto-molecules. Thus, according to Indabawa and Arzai (2011), during the liquid-liquid extraction, 
phyto-molecules are distributed between the solvents according to their polarity and solubility. It can be thus concluded that the active antimicrobial compound contained in the $C$. adenogonium leaf are more soluble in these solvents (ethanol, water-ethanol, methanolic and ethyl acetate).

For used plant extracts, mortality of the Artemia salina is observed in the DL50 of 27,66 $\mathrm{mg} \mathrm{mg/ml;} 4.39 \mathrm{mg} / \mathrm{ml} ; 3.29 \mathrm{mg} / \mathrm{ml} ; 3.04 \mathrm{mg} / \mathrm{ml}$ and 2.87 $\mathrm{mg} / \mathrm{ml}$ respectively for methanolic, aqueous, ethyl acetate, water-ethanol and ethanol extracts. All samples tested, the ethanol extract proved the more toxic to a concentration of $2.87 \mathrm{mg} / \mathrm{ml}$ against the methanolique snippet which showed the lowest rate of toxicity to a concentration of $27,66 \mathrm{mg} . \mathrm{ml}$. these results confirm those of Novatus et al. (2012) which showed that the hydro-ethanol extract of leaves have a slight toxicity to brine shrimp with $\mathrm{DL}_{50}$ values of $76.965 \mathrm{mg} / \mathrm{ml}$. This test has provided us with evidence that different extracts of leaves of $C$. adenogonium have a topical cytotoxic effect in this model of toxicity at the Artemia salina. Based on the correlation linking the degree of toxicity proposed by researchers Moshi et al. (2004) who affirmed that the extracts are non-toxic to the $\mathrm{DL}_{50} \geq 100 \mu \mathrm{g} / \mathrm{ml}, C$. adenogonium is non-toxic regardless the concentrations determined in our study. The mechanism of toxicity may be related to inhibition of the hydrolytic enzymes (proteases and the carbohydrolases) or other interactions to inactivate microbial adhesins, protein transport and cell envelope (Cowan, 1999). Ultimately speaking of biological activity of $C$. adenogonium, acetatique extract is the best choice by its action both on the strains on the research of bioactive molecules.

\section{Conclusion}

It may be concluded that $C$. adenogonium extracts have many secondary metabolites and showed the interesting biological activities. Quantitative screening showed that methanol extract which contain highest amount of phenolic compounds and appreciable amount of flavonoids and ethyl acetate which contain highest amount of flavonoïds exhibited the greatest reducing power as Equivalent Ascorbic acid content. These effects have been correlated to the flavonoid and total phenolic contents of the leaf, indicating that phenolic compounds could be the major contributors to these activities. Additional work is need to determine whether these phenolic constituents are responsible for the antioxidant activity of $C$. adenogonium extracts. Though the extracts have a good inhibitory diameter, the most of them have $\mathrm{MBC}>20 \mathrm{mg} / \mathrm{ml}$ so don't have a good antimicrobial activity. Considering the traditional use and knowledge with present scientific investigation, it would be interesting to study other biological activities such as the anti-inflammatory activity, antiviral, antifongic, antidiuretic activity for the health-promoting properties and pharmaceutical applications. 


\section{Acknowledgement}

The authors thank the government of Benin and the CNS Maïs for financial support.

\section{References:}

1. Aruoma O. I. (1998). Free radicals, oxidative stress and antioxidants in human health and disease. Journal of the American Oil Chemist Society 75, 199 - 212pp.

2. Defraigne, J. O. and pass J. (2007). Antioxidants and oxidative stress: myths and realities. Rev Med Liege. 62, 4 p.

3. Konan F. K., Guessennd N. K., Kelly K. R., Bahi C., Christopher A., Sean A. J. \& Dosso M. (2014). Int. J. biol. Chem. Sci. 8 (3), 1192 $1201 \mathrm{pp}$.

4. Walsh V. (2003). Antibiotics: Actions, Origins, Resistance. ASM Press: Washington, DC

5. Savard P. Y. (2003). Characterization of structural and dynamic of the beta-lactamase TEM-1 of the bacterium Escherichia coli by liquid NMR, Philosophiae Doctor of Biochemistry and microbiology, Faculty of Sciences and engineering, Laval University, Québec, $224 p$.

6. Lozniewski A. (2010). Bacterial resistance to antibiotics, tips for the prevention of the risk infectious-Infections associated with care, CCLIN, Southeast, Nancy, $4 \mathrm{p}$

7. Kone D. (2009). Ethnobotanical survey of six medicinal plants Malian-extraction, identification of alkaloids-characterization, quantification of polyphenols: study of their antioxidant activity. Thesis of doctorate in organic chemistry, universities Paul Verlaine of Metz-UPV-M (France) and Bamako, 157p.

8. Adjanohoun E. J., Adjakidje V., M. R. A., Ake Assi A.o. L,. Akoegninou A., Almeida J., Akpovo F., Bouke K., Castro M., Cusset G., Dramane K., Eyme J., Gassita j. N., Gardner N., Goudote E., Dan S., Hougnon P., Issa L. O., Keita A., Kiniffo H.V., Kone-Bamba D., Musampa Nseyya A., Saadou M., Sodogandji th., Souza S., Tchabi A., Zinsou D. C. and Zohoun Th. (1989) contribution to plant in people's Republic and Ethnobotanical studies Benin. Pharm. Trad Med. ACCT, 895p.

9. Sinsin B., Sinandouwirou Th and Assogbadjo, A. (2000). Two species ecological characterization fodder of Benin: Khaya senegalensis (fstds) and Afzelia africana. sm Report IPGRI/SAFORGEN, Cotonou, Bénin. 
10. Maregesi S. M., Pieters L., Ngassapa o. D. Apers, Vingerhoets, a., Cos P. Vanden Berghe D.A. and Vlietinck A. J. (2008). Screening of some Tanzanian medicinal plants from Bunda district for agents, antifungal and antiviral activities. J Ethnopharmacol. 119:58 - 66pp.

11. Houghton D. J. P. and Raman a. (1998). Laboratory handbook for the fractionation of natural. Extracts. Science. 199p.

12. Dah-Nouvlessounon D., Adoukonou-Sagbadja H., Diarrassouba N., Sina H., Adjonohoun A., Inoussa M., Akakpo D., Gbenou J. D., Kotchoni S. O., Dicko M. H., Baba-Moussa L., (2015). Phytochemical analysis and biological activities of Cola nitida bark. Biochemistry Research International. 2015, 1-12.

13. N'Guessan J.D., Bidie A.P., Lenta B.N., Weniger B., Andre P. \& Guede Guina F. (2007). In vitro assays for bioactivity-guided isolation of antisalmonella and antioxidant compounds in Thonningia sanginea flowers. African Journal of Biotechnology. 6: 1685 - 1689.

14. Harborne J. B. (1998) Nature Methods: A guide to modern techniques of plant analysis. Ed 3. CHAPMAN \& HALL. 202 209pp.

15. Singleton V . L . , Orthofer R . \& Lamuela-Raventos R . Mr. (1999). Analysis of total phenols and other substrates by means of FolinCioalteau reagent antioxidant and oxidation. Meth Enzymol. 299,152 - 178 pp.

16. Kim H. P., sound K. H., Chang H. W. \& Kong S. S. (2004). Antiinflammatory plant flavonoids and cellular action macanism. $J$. Pharmaco. Sci. 96: 229-254pp.

17. Lamian-Meda A., Lamian C. E., Compaoré Mr. M. H., Meda N T. R., Mark M., Zeba B., Masters J. F. . (2008). Polyphenol content and antioxidant activity of fourteen wild edible fruit from Burkina Faso. Molecules. 13 (3): 581-594 pp.

18. Bauer A. W., M. W. Kirby, Sherris J C. and Thomas M. (1966). Antibiotic susceptibility testing by a standardized single disk method. American Journal of Clinical Pathology. 45, 493-496pp.

19. Adewale A., Morgan W. A., Corcoran O. and Chimezie F. (2012) agents activity and in vitro blast of extracts and fractions of Parkia biglobosa (Jacq.) Benth. stem bark and Ageratum plant Linn. Environmental toxicology and pharmacology leaves. 34, 478-483pp.

20. Delarras c. (1998). Microbiology. 90 hours of practical work. Gaétan Morien Publisher, ISBN: 291074907 X, 9782910749071, 169-178 pp. 
21. Kawsar s. A., Huq E. \& Nahar N. (2008). Blast assessment of the aerial part of Macrotyloma uniflorum Lim. Int J Pharm, 4:297 300pp.

22. Novatus F Mushi, Zakaria H Mbwambo, Innocent, \& Supinya Tewtrakul Ester. (2012). agents, anti-HIV-1 protease and cytotoxic activities of aqueous ethanolic extracts from Combretum adenogonium Steud. Ex A. Rich (Combretaceae). Complement Altern Med. 12: 163pp.

23. Tsuchiya H., Sato M., Miyazaki, T., Fujiwara, S., Tanigaki S., M. \& Tanaka, T. Ohyama (1996). Study comparative Iinuma M. on the antibacterial activity of flavanones phytochemicals against Staphylococcus aureus Methicillin resistant J Ethnopharmacol. 50: 27 - 34pp.

24. Ojewole J. A. O. (2008). Analgesic and effects anti - inflammatory molliques Acid glucoside, a 1 $\alpha$-Hydroxycycloartenoid saponin extractive of Combretum MOLLE R. Br. ex G. Don (Combretaceae) sheet Phytother Res. 22: 30-35pp.

25. O. Yahaya and al. (2012)

26. MacDonald (2010). Study of the phythochimie, the anti-radical activity and sub-chronique toxicity of the leaves of Sclerocarya birrea(A.Rich) Hoscht (Anacardiaceae), used in the traditional treatment of diabetes in Mali. PhD thesis, Faculty of medicine and pharmacy, and Odonto-Stomatology of the University of Bamako, $106 \mathrm{p}$.

27. Karou D., Dicko Mr. H., Simpore J.\& Traoré A. S. (2005). Carnosine and agents activities of polyphenols from ethnomedicinal plants of Burkina Faso. Afr. J. Biotechnol., 4 (8): 823 - 828pp.

28. Zakaria Z. A., Rofiee M. S., Mohamed A. M., The L. K. and Salleh M. Z. (2011). In Vitro Antiproliferative and Antioxidant Activities and Total Phenolic Contents of the Extracts of Melastoma malabathricum Leaves. J Acupunct Meridian Stud. 4: 248-256pp.

29. Mada S. B., Garba A., Mohammed H. A., Muhammad A. and Olagunju A. (2013). Antimicrobial activity and phytochemical screening of aqueous and ethanol extracts of Momordica charantia L. leaves, Journal of Medicinal Plants Research., 7(10):579-586pp.

30. Babbs C. F., (1992). Oxygen radicals in colitis therapy. Free Radical Biology and Medicine 13: 169 - 181pp.

31. Gey K.F. (1998). Vitamin E plus C and interacting conutrients required for optimal health. Critical and constructive review of epidemiology and supplementation data regarding cardiovascular disease and cancer. Biofactors. 7: 113 - 174pp. 
32. Zhu Y.Z., S.H. Huang, Tan B.K.H., Sun J., M. and Zhu Whiteman, Y - C. (2004) Antioxidants in Chinese herbal medicines: a biochemical perspective. Natural Product Reports 21: 478 - 489pp.

33. Batawila K., Kokou K., Koumaglo, K., Gbeassor M., De Foucault B., Bouchet, P., and Akapanaga, K. (2005) Antifungal activities of five Combretaceae in Togolese traditional medicine, Fitoterapia, 76 (2) 2 64 - 268pp.

34. Fyhrquist P., Mwasumbi L. Vuorela, Vuorela H., Hiltunen, a., Murphy C. and Adlercreutz H. (2006). Preliminary antiproliferative effects of some species of Terminalia, Combretum and Pteleopsis collected in Tanzania we some human cancer cell lines. Fitoterapia, 77: 358 - 366pp.

35. Hamid A.A. and O.O. Aiyelaagbe (2011). Preliminary nature, agents and Antifungal Properties of Alafia barteri Stem Grown in Nigeria. European Journal of Medicinal Plants. 1: 26-32pp.

36. Kola K. A., Benjamin A. E. \& Danladi N. B. (2002). Comparative October activities of the leaves of Combretum micranthum and $C$. racemosum. Global Journal of Medical Sciences. 1: 13-17pp.

37. Adewale A., Morgan W. A., Corcoran O. \& Chimezie F. (2012). Antibacterial activity and in vitro cytotoxicity of extracts and fractions of Parkia biglobosa (Jacq.) Benth. stem bark and Ageratum conyzoides Linn. Leaves environmental toxicology and pharmacology. 34, 478-483pp.

38. Moshi M. J., Cosam J.C., Mbwambo Z. H., Kapingu M. \& Nkunya M. H. H. (2004). Testing Beyond Ethnomedical Claims: brine shrimp lethality of some Tanzanian plants.Pharmaceutical Biology. 42, 547$551 \mathrm{pp}$.

39. Sparkling M. (1995). Test of toxicity on larvae ofArtemia salina : maintenance of a breeding of

40. Is Henry K., k B., Zirihi G. N., Traoré D.\& Ake Assi L. (2009). Screening phytochemical of some Ivorian medicinal plants used in country Krobou (Agboville, Ivory Coast). Science and Nature. 6: 1 $15 \mathrm{pp}$

41. Cowan M. M. (1999). Plant Products have Canada agents. Clinical Microbiology Reviews, 12 (4): 564-582pp. 